\title{
PENGARUH PENGGUNAAN MEDIA PEMBELAJARAN DAN KONSEP DIRI SISWA TERHADAP HASIL BELAJAR MATEMATIKA SISWA
}

\author{
Indra Cahya Firdaus \\ Teknik Informatika, Universitas Pamulang \\ Email : dosen01376@unpam.ac.id
}

\begin{abstract}
ABSTRAK
Media penelitian yang digunakan adalah survey dan eksperimen dengan media analisis teatment by level. Jenis pungujian yang digunakan adalah Anova Dua Arah. Eksperimen dilakukan pada dua kelompok/sampel dimana masing-masing kelompok diberi perlakuan (treatment) yang berbeda. Kelompok pertama diajar dengan menggunakan media pembelajaran pesona matematika, sedangkan kelompok kedua diajar dengan menggunakan media pembelajaran konvensional. Masing-masing kelompok dibagi lagi menjadi dua kategori menurut Konsep Diri, yaitu kelompok yang mempunyai Konsep Diri kategori tinggi dan kelompok yang mempunyai Konsep Diri kategori rendah. Tujuan dari penelitian ini adalah untuk mengetahui sejauh mana pengaruh penggunaan media pembelajaran, dalam penelitian ini adalah media pembelajaran dan Konsep Diri terhadap hasil belajar matematika siswa, khususnya untuk siswa XI MA. Ada pengaruh yang positif dan signifikan maka seberapa kuat pengaruh penggunaan penggunaan media pembelajaran pesona matematika dan Konsep Diri terhadap hasil belajar matematika siswa.
\end{abstract}

Kata Kunci : Multimedia,E-Learning,Media pembelajaran pesona matematika, Konsep Diri, Hasil Belajar

\section{PENDAHULUAN}

Memasuki abad ke-21 sistem pendidikan nasional menghadapi tantangan yang sangat kompleks dalam menyiapkan kualitas sumber daya manusia (SDM) yang mampu bersaing di era global. Pendidikan yang mampu mendukung pembangunanan di masa mendatang adalah pendidikan yang mampu mengembangkan potensi perserta didik, sehingga yang bersangkutan mampu menghadapi dan memecahkan problema kehidupan yang dihadapinya. Pendidikan harus menyentuh potensi nurani maupun potensi kompetensi peserta didik. Konsep pendidikan tersebut semakin penting ketika peserta didik nantinya memasuki kehidupan di masyarakat dan dunia kerja, sehingga apa yang dipelajari di sekolah harus mampu menerapkannya dalam kehidupan sehari-hari saat ini maupun di masa yang akan datang.

Pendidikan menengah merupakan salah satu jenjang pendidikan yang berlaku dalam sistem pendidikan nasional. Penyelengaraan pendidikan menengah merupakan suatu proses yang berlangsung selama 3 tahun dan dalam rangka melaksanakan program pendidikan untuk mencapai tujuan pendidikan nasional. Penyelenggaraan pendidikan menengah kejuruan merupakan suatu sistem, sebagai suatu sistem pada hakekatnya penyelenggaraan pendidikan menengah kejuruan merupakan suatu keseluruhan yang meliputi komponen-komponen masukan, proses dan kelulusan. Dengan demikian ketiga komponen di atas merupakan komponen-komponen yang mendukung penyelenggaraan pendidikan di sekolah menengah kejuruan.

\section{Matematika dan Pembelajaran Matematika} Matematika merupakan ilmu universal yang mendasari perkembangan teknologi modern, mempunyai peran penting dalam berbagai disiplin dan mengembangkan daya pikir manusia. Perkembangan pesat, dibidang teknologi informasi dan komunikasi dewasa ini dilandasi oleh pekermbangan matematika di bidang teori bilangan, aljabar, analisis, teori peluang dan matematika diskrit. Untuk menguasai dan mencipta teknologi di masa depan penguasaan matematika yang kuat sejak dini..

Rendah hasil pembelajaran matematika disebabkan banyak hal antara lain : kurikulum yang padat, media belajar yang kurang efektif, materi pada buku pelajaran yang dirasakan terlalu banyak sulit untuk di ikuti, kurang tepatnya strategi dan metode pembelajaran yang dipilih oleh guru yang kurang optimal dan kurangnya keselarasan siswa itu sendiri, atau sifat konvesional, dimana siswa tidak banyak terlibat 
dalam proses pembelajaran dan keaktifan kelas sebagian besar didominasi oleh guru.

Media pembelajaran mulanya hanyalah dianggap sebagai alat bantu guru dalam kegiatan mengajar. Alat bantu mengajar yang mula-mula digunakan adalah alat bantu visual seperti gambar, model, grafis atau benda lain kemudian pertengahan abad 20 pemanfaat media visual dilengkapi dengan peralatan audio maka lahirlah audio visual pembelajaran dan diakhir tahun 1950, teori komunikasi memengaruhi penggunaan alat audio visual sehingga media bukan hanya sebagai alat bantu guru tetapi juga berfungsi sebagai penyalur pesan belajar.

Sejalan dengan perkembangan ilmu pengetahuan dan teknologi yang semakin pesat yang merupakan salah satu hasil produktivitas dari manusia yang memiliki pengetahuan yang didapat dari pendidikan. Fenomena berkembangnya teknologi informasi dan komunikasi (TIK) dengan munculnya internet dan layanan pembelajaran seperti : e-Learning, $e$ Library, dan layanan administrasi sekolah seperti e-Filling, e-Finance dan lain-lain. Dan hal ini bagi lembaga pendidikan harus mampu memberdayakan dan memanfaatkan dalam proses belajar mengajar untuk menghasilkan SDM yang berkualitas dan mampu bersaing dalam percaturan global.

Perkembangan Ilmu Pengetahuan dan Teknologi menuntut adanya perbaikan sistem pengajaran. Metode-metode pembelajaran baru telah bermunculan, sebut saja metode pembelajaran baru yang menggunakan media pembelajaran. Media yang sederhana, konvensional, dan murah harganya, hingga media yang kompleks, rumit, modern, dan harganya sangat mahal. Mulai dari yang hanya merespon indera tertentu, sampai yang dapat merespon perpaduan dari berbagai indera manusia.Dari yang hanya secara manual dan konvesional dalam pengoperasiannya, hingga yang sangat tergantung pada perangkat keras dan kemahiran sumber daya manusia tertentu dalam pengoperasiannya. (Angkowo, R. dan Kosasih, A :2007 : 12).

\section{Media Pembelajaran Teknologi Informasi dan Komunikasi}

Media pembelajaran sangat menentukan keberhasilan proses belajar mengajar, pada umumnya media pembelajaran masih bersifat konvensional sehingga memengaruhi minat siswa terhadap pelajaran matematika. Dan hal itu perlu diubah dengan menggunakan media pembelajaran teknologi informasi dan komunikasi (ICT) sehingga proses belajar mengajar menjadi lebih interaktif.

Media pembelajaran berbasis internet $(e$ learning) mulai diterapkan sejak tahun 1970-an (Walker \& Wilson, 2001). Menurut Siahaan (2002) setidaknya ada tiga fungsi pembelajaran $e$ learning terhadap kegiatan pembelajaran, yaitu sebagai berikut :

1) Sebagai suplemen pembelajaran yang sifatnya pilihan/opsional.

E-learning berfungsi sebagai suplemen (tambahan), apabila peserta didik mempunyai kekebesan memilih, apakah siswa akan memanfaatkan materi pembelajaran elektronik atau menggunakan pembelajaran konvensional. Sekalipun opsional, siswa yang memanfaatkannya tentu akan memiliki tambahan pengetahuan atau wawasan.

2). Sebagai pelengkap (komplemen) pembelajaran

E-learning berfungsi sebagai komplemen pembelajaran apabila materi pembelajaran diprogramkan untuk melengkapi materi pembelajaran yang diterima siswa di dalam kelas konvensional (Lewis, 2002). Sebagai komplemen berarti pembelajaran elektornik diprogramkan untuk menjadi materi pengayaan atau remedial bagi siswa di dalam mengikuti kegiatan pembelajaran konvensional.

3). Sebagai pengganti (substitusi) pembelajaran

E-learning sebagai pengganti jika pembelajaran elektronik sepenuhnya digunakan dalam proses pembelajaran. Dalam kondisi ini, siswa hanya belajar lewat pembelajaran elektronik saja, tanpa menggunakan model pembelajaran lainnya.Dalam kegiatan belajar dibatasi beberapa hal antara lain adalah kurangnya konsep diri yang dimiliki oleh siswa sehingga hasil belajar siswa tersebut belum memenuhi harapan. Karena kurangnya konsep diri sehingga siswa kurang menguasai materi yang diberi oleh guru.Walaupun secara umum siswa kurang berminat terhadap pelajaran matematika namun masih ada siswa berminat menekuni matematika, alasannya apabila nanti melanjutkan ke sekolah yang lebih tinggi yaitu masuk ke SMA (Sekolah Menengah Atas) jurusan matematika dan kemudian ke Perguruan Tinggi atau 
Teknik. Dorongan oleh minat inilah sehingga siswa memiliki keinginan untuk menguasai/memahami pelajaran matematika.

Software PesonaEdu VERSI ONLINE merupakan jawaban atas tuntutan bahwa pendidikan tidak hanya tanggung jawab Sekolah namun juga Orang Tua. Diharapkan dengan hadirnya PesonaEdu Software ke rumah-rumah, kini anak-anak semakin tertarik dan gemar belajar khususnya untuk pelajaran Matematika dan Sains.

\section{Konsep Diri}

Konsep diri adalah pandangan dan sikap individu terhadap kemampuan dirinya sendiri, dan konsep diri mempunyai peran penting dalam menentukan dan mengarahkan seluruh tingkah laku individu. Peranan penting tersebut ditunjukkan dengan kenyataan bahwa setiap individu selalu berusaha untuk memperoleh keseimbangan dalam dirinya, selalu dihadapkan pada pengalaman hidup, dan selalu dipenuhi oleh kebutuhan untuk mencapai prestasi. Perbedaan keseimbangan antara pengalaman hidup dan kebutuhan untuk mencapai prestasi antara individu yang satu dengan individu yang lain, maka akan menyebabkan perbedaan tafsiran tentang dirinya sendiri. Seseorang yang mempunyai tafsiran negative terhadap pengalaman hidup yang dialaminya, maka akan menyebabkan pandangan dan sikap negatif terhadap diri sendiri. Sebaliknya seseorang yang mempunyai tafsiran positif terhadap pengalaman hidup yang dialaminya, maka akan menyebabkan pandangan hidup dan sikap positif terhadap dirinya sendiri.Singkatnya, sikap dan pandangan negatif terhadap diri sendiri menyebabkan individu memandang seluruh hidupnya dengan penuh rasa pesimis, penuh ketidak-mampuan dan kurang percaya diri. Sikap dan pandangan yang positif terhadap diri sendiri menyebabkan individu memandang seluruh hidupnya dengan penuh rasa percaya diri dan selalu merasa optimis.

Selanjutnya dalam penelitian ini, konsep diri yang akan diteliti dibagi atas dua bagian: (a) percaya diri (self confidence), yang merupakan keyakinan seseorang akan kemampuan atau kesanggupannya untuk melaksanakan tugas atau pekerjaan, dan (b) harga diri (self esteem), merupakan perasaan dan nilai yang dimiliki seseorang tentang bagaimana baiknya orang tersebut menginginkan dirinya.

\section{Hasil Belajar Matematika}

Hasil belajar diartikan sebagai penguasaan pengetahuan oleh seorang siswa yang diperoleh setelah mengikuti kegiatan pembelajaran selama jangka waktu tertentu. Biasanya dinyatakan dengan sebuah nilai sesuai dengan kemampuannya yang diberikan oleh guru. Hasil belajar mata pelajaran matematika merupakan kegiatan dari belajar matematika dalam bentuk pengetahuan sebagai akibat dari perlakuan atau pembelajaran yang dilakukan oleh siswa. Dalam penelitian ini, hasil belajar adalah penguasaan pengetahuan dalam materi matematika yang dikuasai oleh seorang siswa. Menurut Bruner, persoalan inti dari belajar memecahkan masalah matematika terletak pada bagaimana informasi yang didapatkan disimpan di dalam memori sedemikian rupa sehingga mudah dipanggil (retrieved) pada saat diperlukan. Saat yang dimaksud adalah ketika seseorang dihadapkan pada situasi atau permasalahan yang polanya baru.

\section{Tujuan Penelitian}

1) Penelitian ini bertujuan untuk mengetahui berapa besar pengaruh :

1) Media pembelajaran terhadap hasil belajar matematika

2) Konsep diri terhadap hasil belajar matematika

3) Media pembelajaran dan konsep diri berinteraksi terhadap hasil belajar matematika siswa

\section{Hipotesis Penelitian}

Berdasarkan deskripsi teori dan kerangka berpikir di atas, maka dalam penelitian ini diajukan hipotesis yakni :

1. Terdapat pengaruh media pembelajaran terhadap hasil belajar matematika.

2. Terdapat pengaruh Konsep diri terhadap hasil belajar matematika.

3. Terdapat pengaruh interaksi antara media pembelajaran dan Konsep diri terhadap hasil belajar matematika.

\section{METODE PENELTIAN}

Tempat dan Waktu Kegiatan

Penelitian ini dilakukan di Madrasah Aliyah (MA) Daar El Azhar di Kota Administrasi Lebak. Di wilayah tersebut terdapat 2 buah MA pada Pendok Pesantren Daar El Azhar dan Pondok Pesantren Daar El-Bayan Rangkasbitung dan Proses penelitian d waktunya sekitar empat bulan dari bulan Juli sampai bulan November tahun 2016, mulai dari penentuan masalah, 
penyusunan proposal dan menyelesaikan laporan penelitian.

\section{Metode Peneltian}

Metode yang digunakan dalam penelitian ini adalah survei dan eksperimen dengan model analisis teatment by level. Jenis pungujian yang digunakan adalah Anova Dua Arah. Eksperimen dilakukan pada dua kelompok/sampel dimana masing-masing kelompok diberi perlakuan (treatment) yang berbeda. Kelompok pertama diajar dengan menggunakan model pembelajaran pesona Matematika, sedangkan kelompok kedua diajar dengan menggunakan model pembelajaran konvensional. Masing-masing kelompok dibagi lagi menjadi dua kategori menurut konsep diri dalam belajar, yaitu kelompok yang mempunyai konsep diri kategori tinggi dan kelompok yang mempunyai konsep diri kategori rendah.

\section{Teknik Pengambilan Sampel}

1) Populasi Target

Populasi target dalam penelitian ini adalah seluruh siswa kelas XI (Sebelas) Madrasah Aliyah (MA) swasta di wilayah Kecamatan Muara Ujung Timur tahun pelajaran 2015/2016.

2) Populasi Terjangkau

Populasi terjangkau dalam penelitian ini adalah seluruh siswa Kelas XI MA Daar El Azhar dan MA Al Bayan 2012/2013. Kondisi anggota populasi terjangkau ini sesuai yang tertera pada

3) Sampel

Sampel penelitian adalah siswa kelas XI MA di wilayah Rangkasbitung. Siswa yang dipilih sebagai sampel penelitian adalah siswa yang tergabung dalam populasi terjangkau kemudian diambil secara random dari 2 kelas. Kedua kelas sampel tersebut akan diberikan pengajaran yang berbeda, yaitu kelas eksperimen diberikan pengajaran menggunakan media Pesona Matematika dan kelas kontrol diberikan pengajaran dengan menggunakan model belajar konvensional. Dari dua kelas yang terpilih, karena setiap kelas hanya akan dipilih 60 siswa sebagai anggota sampel yang diambil dari dua kelas yaitu kelas eksperimen dan kelas kontrol yang dibagi menjadi 4 kelompok yang masing-masing terdiri dari 30 siswa yang kemudian dibagi lagi menjadi 16 siwa dan 14 siswa kelas eksperimen,dan 30 siswa yang kemudian dibagi lagi menjadi
16 siwa dan 14 siswa kelas kontrol lalu anggota sampel tersebut dipilih secara acak tertimbang. Sebagai pertimbangan calon anggota sampel adalah bahwa siswa tersebut tidak termasuk kelompok istimewa, yang dimaksud kelompok istimewa adalah siswa yang terlalu pandai atau sebaliknya, bermasalah dalam kehadiran atau bermasalah dalam kedisiplinan.

4) Teknik Sampling

Sampel penelitian ini ditentukan dengan menggunakan Cluster Sampling atau Intact Clasa. Teknik Cluster Sampling biasanya dilakukan 2 tahap, yaitu :

a. Tahap pertama, pengambilan kelas eksperimen dan kelas kontrol dilakukan dengan teknik sampel random sampling (sampel acak sederhana). Pengambilan sampel kelas dilakukan dengan cara memilih dua kelas bukan unggulan yang memiliki kelas setara. Adapun untuk menentukan kelas sebagai uji coba instrumen diambil kelas yang tidak termasuk sebagai subyek penelitian dan kelas tersebut sebagai kelas uji coba instrumen penelitian.

b. Tahap kedua, pengambilan sampel subyek atau individu dilakukan dengan teknik sampling sistematis. Dalam penelitian ini, sampel subyek atau siswa diambil berdasarkan urutan tingkat konsep dirinya, penulis mengambil beberapa orang siswa yang urutan konsep dirinya tinggi dan beberapa orang siswa yang urutan konsep dirinya rendah pada kelas eksperimen. Selain itu juga beberapa orang siswa yang urutan konsep dirinya tinggi dan beberapa orang siswa yang urutan konsep dirinya rendah pada kelas kontrol

\section{Definisi Konseptual}

Hasil belajar Matematika siswa dalam penelitian ini adalah tingkat pencapaian kemampuan pengetahuan siswa pada materi Matematika, serta pencapaian keterampilan dan sikap yang terkait dengan wawasan tentang Matematika, yang ditunjukkan oleh skor yang diperoleh siswa dalam menyelesaikan soal-soal tentang teori dan konsep Matematika.

Secara konseptual, konsep diri dalam penelitian ini adalah persepsi atau penilaian 
seseorang terhadap dirinya sendiri, yang ditandai dengan indikator: (1) Rasa Tinggi / self confidence, (2) harga diri / self esteem..

\section{Definisi Operasional}

Hasil belajar Matematika siswa adalah skor tentang tingkat pencapaian kemampuan siswa pada aspek pengetahuan, pemahaman dan aplikasi tentang materi pelajaran Matematika yang diukur melalui tes/ulangan dengan soal berbentuk pilihan ganda sebanyak 20 butir dengan 5 pilihan jawaban. Materi pembelajaran yang digunakan dalam penelitian ini adalah statistika.

Secara operasional konsep diri dalam penelitian ini adalah skor yang diperoleh dari angket konsep diri yang telah diberikan kepada responden dengan rentang nilai tertinggi 200 dan terendah 40. Nilai di atas diperoleh dengan memakai skala Likert

\section{Teknik Analisis Data}

1) Teknik Analisis Deskriptif

Dalam analisis deskriptif akan dilakukan teknik penyajian data dalam bentuk tabel disitribusi frekuensi atau histogram/grafik/diagram batang untuk masing-masing kelompok data penguasaan konsep matematika siswa. Selain itu juga masing-masing kelompok data akan diolah dan dianalisis ukuran pemusatan dan letak seperti mean, median, dan modus, varians, simpangan baku.

2) Teknik Persyaratan Analisis Data

Sebelum data dianalisis untuk pengujian hipotesis terlebih dahulu dilakukan uji prasyarat analisis yaitu uji normalitas dan uji homogenitas.

3) Teknik Analisis Uji Hipotesis Penelitian Dalam praktiknya, akan digunakan bantuan program SPSS 17.0 untuk pengujian hipotesis tersebut, yaitu melalui pengujian Anova Dua Arah. Pada pngujian Anova Dua Arah dengan SPSS tersebut, output yang diperhatikan adalah nilai kolom Sig pada tabel Tests of BetweenSubjects Effects.

4) Teknik Uji Lanjut

Pengujian lanjut ini dilakukan untuk pengujian hipotesis 1 yaitu perbandingan antar kolom atau untuk membuktikan ada atau tidaknya pengaruh penggunaan media pembelajaran terhadap hasil belajar Matematika, dan untuk pengujian hipotesis 2 yaitu perbandingan antar baris atau untuk membuktikan ada atau tidaknya pengaruh konsep diri terhadap hasil belajar Matematika.Teknik pengujian lanjut dilakukan dengan menggunakan teknik uji beda rata-rata. Hipotesis statistikanya sama, sedangkan rumus pengujiannya adalah dengan menggunakan rumus Fisher (Sudjana , 1996: 242) sebagai berikut:

$$
\begin{aligned}
& t=\frac{X_{1}-X_{2}}{s \sqrt{\frac{1}{n_{1}}+\frac{1}{n_{2}}}} \\
& \text { dimana } s=\frac{\left(n_{1}-1\right) s_{1}^{2}+\left(n_{2}-1\right) s_{2}^{2}}{n_{1}+n_{2}-2} \\
& \text { dan: } \\
& \mathrm{X}_{1}=\text { rata-rata variabel pertama } \\
& \mathrm{X}_{2}=\text { rata-rata variabel kedua } \\
& \mathrm{n}_{1}=\text { jumlah sampel I } \\
& \mathrm{n}_{1}+\mathrm{n}_{2}-2=\text { derajat kebebasan } \\
& \mathrm{n}_{2}=\text { jumlah sampel I } \\
& \mathrm{s}_{1}=\text { varian sampel II } \\
& \mathrm{s}_{2}=\text { varian sampel II }
\end{aligned}
$$

\begin{tabular}{|c|c|c|c|c|c|}
\hline Source & $\begin{array}{l}\text { Type III } \\
\text { Sum of } \\
\text { Squares }\end{array}$ & Df & Mean Square & $\mathrm{F}$ & Sig. \\
\hline $\begin{array}{l}\text { Corrected Model } \\
\text { Intercept } \\
\text { Media } \\
\text { Konsep Diri } \\
\text { Media * Konsep Diri } \\
\text { Error } \\
\text { Total } \\
\text { Corrected Total }\end{array}$ & \begin{tabular}{r|}
$17160,250^{2}$ \\
182985,565 \\
2004,672 \\
4729,871 \\
100,511 \\
66,333 \\
293987,000 \\
17226,583 \\
\end{tabular} & \begin{tabular}{r|}
29 \\
1 \\
1 \\
22 \\
6 \\
30 \\
60 \\
59
\end{tabular} & \begin{tabular}{|r|}
591,733 \\
182985,565 \\
2004,672 \\
214,994 \\
16,752 \\
2,211 \\
\end{tabular} & $\begin{array}{r}267,618 \\
82757,291 \\
906,636 \\
97,234 \\
7,576\end{array}$ & $\begin{array}{l}, 000 \\
, 000 \\
, 000 \\
, 000 \\
, 002\end{array}$ \\
\hline
\end{tabular}

\section{HASIL DAN PEMBAHASAN}

\section{Hasil Pengujian Hipotesis Penelitian}

Pengujian hipotesis penelitian menggunakan ANOVA dua jalur untuk mengetahui pengaruh dan interaksi antar kelompok. Analisis ANOVA ini menggunakan SPSS 16. Berikut ini adalah tabel ANOVA

Tabel ANOVA

Tests of Between-Subjects Effects

a. R Squared = ,996 (Adjusted R Squared =,992)

Dari tabel Anova di atas terlihat sig 0,002, ini berarti terdapat pengaruh dan interaksi antar kelompok antara penggunaan Media pembelajaran dan Konsep Diri siswa terhadap hasil belajar matematika siswa. Untuk lebih jelasnya diuraikan satu persatu sebagai berkut.

1) Pengaruh Media pembelajaran terhadap Hasil Belajar

Berdasarkan tabel mengenai ringkasan hasil ANOVA di atas terlihat bahwa $\mathrm{F}_{\text {hitung }}$ 906,636 dan sig 0,000<0,05, maka 
hipotesis nol $\left(\mathrm{H}_{0}\right)$ ditolak dan hipotesis alternative $\left(\mathrm{H}_{1}\right)$ diterima. Hal ini membuktikan bahwa perbedaan rata-rata (mean) hasil belajar siswa yang diajar dengan mengunakan Media pembelajaran Pesona Matematika dengan siswa yang diajar dengan media konvensional adalah berbeda secara signifikan. Siswa yang diajar dengan menggunakan Media pembelajaran Pesona Matematika memiliki hasil belajar lebih tinggi daripada siswa yang diajar dengan Media konvensional.Berdasarkan data tersebut, dapat disimpulkan bahwa terdapat pengaruh yang signifikan Media pembelajaran dengan hasil belajar siswa. Dengan kata lain bahwa terdapat perbedaan hasil belajar belajar siswa yang diajar dengan menggunakan Media pembelajaran Pesona Matematika dengan siswa yang diajar dengan Media konvensional.

2) Pengaruh Konsep Diri Terhadap Hasil Belajar Matematika

Berdasarkan tabel mengenai ringkasan hasil ANOVA di atas terlihat bahwa $F_{\text {hitung }}$ 97,234 dan sig $0,000<0,05$, maka hipotesis nol $\left(\mathrm{H}_{0}\right)$ ditolak dan hipotesis alternative $\left(\mathrm{H}_{1}\right)$ diterima. Hal ini membuktikan bahwa perbedaan rata-rata (mean) hasil belajar siswa yang mempunyai Konsep Diri tinggi dengan siswa yang mempunyai Konsep Diri rendah adalah berbeda secara signifikan. Dimana siswa yang mempunya Konsep Diri memiliki perbedaan yang signifikan.Berdasarkan data tersebut, dapat disimpulkan bahwa terdapat pengaruh yang signifikan Konsep Diri siswa pada mata pelajaran matematika dengan hasil belajar siswa. Dengan kata lain, terdapat perbedaan hasil belajar siswa yang memiliki Konsep Diri tinggi dengan siswa yang memiliki Konsep Diri rendah.

3) Pengaruh Interaksi antara Media pembelajaran dan Konsep Diri Siswa (A dan B)

Untuk pengujian hipotesis pengaruh interaksi hasil belajar yang menggunakan Media pembelajaran Pesona Matematika dan yang menggunakan media konvensional pada pelajaran matematika menggunakan perhitungan SPSS 16. Berdasarkan tabel 4.21 di atas didapatkan nilai $F_{\text {hitung }}=7,576$ dan sig 0,002 $<0,05$ maka $\mathrm{H}_{1}$ diterima dan $\mathrm{H}_{0}$ ditolak. Berdasarkan data tersebut dapat disimpulkan terdapat pengaruh interaksi Media pembelajaran dan Konsep Diri terhadap hasil belajar. Berdasarkan hasil ini, maka uji lanjut diperlukan.

4) Uji Lanjut

Sebagai dampak dari adanya pengaruh interaksi antara media belajar dan Konsep Diri terhadap hasil belajar maka dilakukan uji lanjut.

Uji Tukey sering juga disebut dengan uji beda nyata jujur, diperkenalkan oleh Tukey (1953). Prosedur pengujiannya mirip dengan LSD [Least Significant Difference] atau beda nyata jalur, yaitu mempunyai satu pembanding dan digunakan sebagai alternatif pengganti LSD apabila kita ingin menguji seluruh pasangan ratarata perlakuan tanpa rencana. Uji Tukey digunakan untuk membandingkan seluruh pasangan rata-rata perlakuan setelah uji Analisis Ragam di lakukan.

Pengujian lanjut atau hipotesis simple effect ini dapat dilakukan dengan menggunakan Uji Tukey (jika banyaknya data masing-masing kelompok sama). Pengujian hipotesis ini (uji lanjut) perlu dilakukan, jika dalam pengujian hipotesis interaction effect diperoleh interaksi yang signifikan.

Berikut adalah tabel uji lanjut dengan Uji Tukey pengaruh interaksi Media pembelajaran dan Konsep Diri terhadap hasil belajar.

\section{Tabel Uji Tukey}

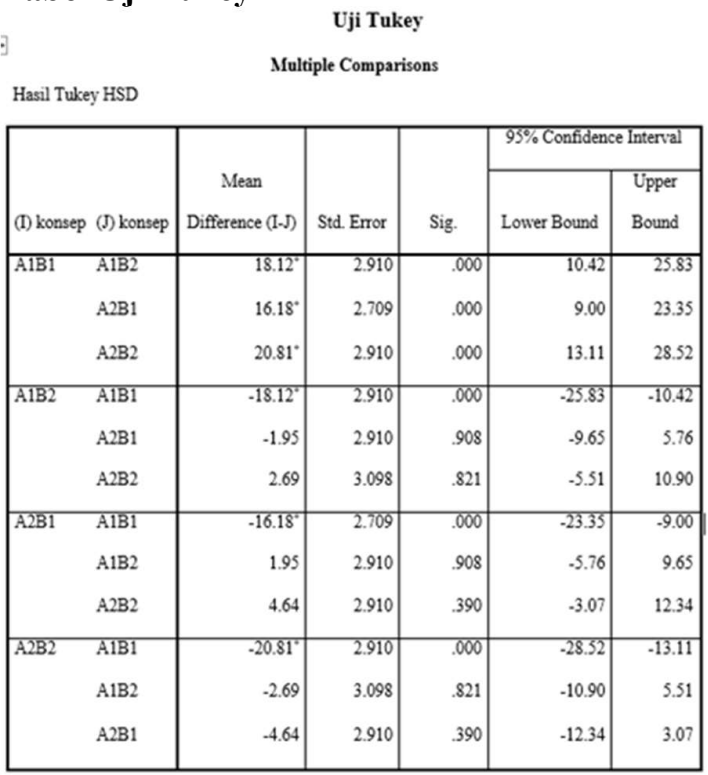



bahwa:

Dari uji Tukey di atas dapat di jelaskan

a) Pengaruh Media pembelajaran Pesona Matematika dan Konsep Diri Tinggi (A1B1) dengan Media pembelajaran Pesona Matematika dan Konsep Diri Rendah (A1B2)

Pada tabel diatas terlihat bahwa mean difference sebesar 18,12, artinya selisih antara rerata kelompok A1B1 dan A1B2 sebesar 18,12. Nilai ini cukup besar dan dapat dibuktikan dengan nilai signifikansi $0,000<0,005$, atau dapat diartikan bahwa kelompok A1B1 dan A1B2 berbeda secara signifikan.

b) Pengaruh Media Konvensional dan Konsep Diri Tinggi (A2B1) dengan Media Konvensional dan Konsep Diri Rendah (A2B2)

Pada tabel diatas terlihat bahwa mean difference sebesar 4,64, artinya selisih antara rerata kelompok A2B1 dan A2B2 sebesar 4,64. Nilai ini cukup kecil dan dapat dibuktikan dengan nilai signifikansi $0,390>0,005$, atau dapat diartikan bahwa kelompok A1B1 dan A1B2 tidak berbeda secara signifikan.

c) Pengaruh Media pembelajaran Pesona Matematika dan Konsep Diri Tinggi (A1B1) dengan Media pembelajaran dan Konsep Diri Rendah (A2B1)

Pada tabel diatas terlihat bahwa mean difference sebesar 16,18, artinya selisih antara rerata kelompok A1B1 dan A2B1 sebesar 16,18. Nilai ini cukup besar dan dapat dibuktikan dengan nilai signifikansi $0,000<0,005$, atau dapat diartikan bahwa kelompok A1B1 dan A2B1 berbeda secara signifikan.

d) Pengaruh Media pembelajaran Pesona Matematika dan Konsep Diri Rendah (A1B2) dengan Pembelajaran Konvensional dan Konsep Diri Rendah (A2B2)

Pada tabel diatas terlihat bahwa mean difference sebesar 2,69, artinya selisih antara rerata kelompok A1B2 dan A2B2 sebesar 2,69. Nilai ini cukup kecil dan dapat dibuktikan dengan nilai signifikansi $0,821>0,005$, atau dapat diartikan bahwa kelompok A1B2 dan A2B2 tidak berbeda secara signifikan.

\section{Pembahasan}

Belajar adalah suatu aktivitas yang dilakukan secara sadar untuk mengubah perilaku seseorang. Menurut Hilgard, belajar adalah proses perubahan melalui kegiatan atau prosedur latihan, baik latihan di dalam laboratorium maupun di dalam lingkungan alamiah. Belajar adalah suatu proses usaha yang dilakukan oleh seseorang untuk memperoleh suatu perubahan yang baru, sebagai hasil pengalamannya sendiri dalam interaksi dengan lingkungannya (M. Sobry Sutikno:2004). [3]. Perubahan perilaku tersebut tercermin dari kemampuan, Konsep Diri, dan keterampilan seseorang sebagai hasil dari belajar. Dalam proses belajar, secara garis besar terdapat dua faktor yang mempengaruhi yaitu faktor yang datang dari dalam diri siswa dan faktor yang datang dari luar diri siswa. Salah satu faktor yang datang dari dalam diri siswa adalah Konsep Diri siswa pada pelajaran.

Konsep Diri adalah semua ide, pikiran kepercayaan dan pendirian yang diketahui individu tentang dirinya dan mempengaruhi individu dalam berhubungan dengan orang lain. Ide-ide, pikiran, perasaan, dan keyakinan ini merupakan persepsi yang bersangkutan tentang karakteristik dan kemampuan interaksi dengan orang lain dan lingkungan, nilai yang berkaitan dengan pengalaman dan objek sekitarnya serta tujuan dan idealismenya. Konsep Diri adalah cara individu memandang dirinya secara utuh baik fisik, emosi, intelektual, social, dan spiritual. Meskipun Konsep Diri adalah milik seseorang secara individual, ternyata Konsep Diri juga terbentuk melalui interaksi dengan orang lain dan mengacu pada bagaimana pendapat orang tentang dirinya. Seperti yang dikatakan Deddy Mulyana yang mendefinisikan Konsep Diri sebagai "pandangan kita mengenai siapa diri kita, dan itu hanya bisa kita peroleh lewat informasi yang diberikan oleh orang lain kepada kita" (Dedi Mulyana, 2001: 7).

Belajar adalah proses aktif dan konstruktif melalui suatu pengalaman dalam memperoleh informasi. Dalam proses aktif tersebut, Media pembelajaran berperan sebagai salah satu sumber belajar bagi siswa. Artinya melalui media siswa memperoleh pesan dan informasi sehingga membentuk pengetahuan baru pada siswa. Dalam batas tertentu, media dapat menggantikan fungsi guru sebagai sumber informasi/pengetahuan bagi peserta didik. Media pembelajaran sebagai sumber belajar merupakan suatu komponen system pembelajaran yang meliputi pesan, orang, bahan, alat, teknik, dan lingkungan, yang dapat mempengaruhi hasil belajar peserta didik. 
(Mudhoffir, dalam Munadi, 2008). Untuk mengetahui pengaruh Media pembelajaran tersebut maka yang dijadikan media dalam penelitian ini adalah media Pesona Matematika dan media konvensional.

Mengacu pada hasil penelitian dan didukung oleh analisi statistik untuk penelitian tentang hasil belajar, diperoleh kesimpulan bahwa data berasal dari populasi berdistribusi normal dan berasal dari varians yang sama (homogen). Dengan demikian maka data yang ada telah memenuhi uji prasyarat analisis data.

\section{KESIMPULAN}

Hasil penelitian menunjukkan bahwa secara signifikan terdapat pengaruh interaksi media pembelajaran dan konsep diri terhadap hasil belajar Matematika. Siswa yang diajar dengan media pembelajaran Pesona Matematika terdapat perbedaan dengan siswa yang diajarkan dengan media pembelajaran konvensional. Dalam media pembelajaran dituntut kemampuan guru untuk menggali segala potensi dan kreatifitas siswa. Media pembelajaran digunakan dalam rangka upaya peningkatan atau mempertinggi mutu proses kegiatan belajarmengajar.

\section{DAFTAR PUSTAKA}

Arikunto Suharsimi, 2012, Dasar-dasar Evaluasi Pendidikan. Jakarta : PT. Bumi Aksara

Azhar Arsyad, 1996, Media Pembelajaran. Jakarta : Rajawali Pers

Bambang Suhendro, 2006, Model Silabus dan Rencana Pelaksanaan Pembelajaran, Jakarta : Departemen Pendidikan Nasional

Cormentyna Sitanggang, 2003, Kamus Matematika. Jakarta : PT. Balai Pustaka

Dedy Mulyana, 2001, Pengantar Ilmu Komunikasi. Bandung : Remaja Rosdakarya

Depdiknas. 2006. Kurikulum Tingkat Satuan Pendidikan, Jakarta Depdiknas

Dewi Salma Prawiradilaga dkk, 2007, Mozaik Teknologi Pendidikan. Jakarta : Prenanda Media Group

Dewi Salma Prawiradilaga, 2004, Mozaik Teknologi Pendidikan. Jakarta : Kencana Prenada Media Group.

Didik Wijaya, 2003, Macromedia Flash MX dengan ActionScript. Jakarta : Elex Media Komputindo

Djaali, 2008, Psikologi Pendidikan. Jakarta : Bumi Aksara.

Duwi Priyatno, 2012, Belajar Cepat Olah Data Statistik dengan SPSS. Yogyakarta : Andi

Emzir, 2008, Metodologi Penelitian Pendidikan Kuantitatif \& Kualitatif. PT. Rajagrafindo Persada.
Erman Suherman dkk, 2001, Strategi Pembelajaran Matematika Kontemporer. Bandung : JICA

Hamalik, Oemar, 2004. Proses Belajar Mengajar. Jakarta: PT. Bumi Aksara

Hamid Muhammad, 2005, Materi Pelatihan Terintegrasi IPA. Jakarta : Departemen Pendidikan Nasional.

Hamzah Uno dkk, 2000, Perencanaan Pembelajaran. Jakarta : Alawiyah Press.

Jalaludin Rakhmat, 2003, Psikologi komunikasi. Bandung : Remaja Rosdakarya

M. Sobry Sutikno, 2004, Belajar dan pembelajaran. Jakarta : Holitica

M. Sobry Sutikno, 2007, Strategi Belajar Mengajar. Bandung: PT. Rineka Cipta.

Muhammad Adri, 2003, Pemanfaatan Teknologi Informasi dalam Pengembangan Media Pembelajaran, http:// muhammadadri.wordpress.com.

Rahmani Astuti, 2003, Revolusi belajar untuk anak. Bandung : Kaifa

Singgih Santoso, 2006, Menguasai Statistik di Era Informasi dengan SPSS 15,

Stanislaus S. Uyanto, 2006, Pedoman Analisis Data dengan SPSS, Jakarta : Graha Ilmu.

Supardi, 2012, Aplikasi Statistika Dalam penelitian. Jakarta : Ufuk Edu

Suparman Ibrahim Abdullah, 2012, Aplikasi Komputer Dalam Penyusunan Karya Ilmiah (SPSS, Minitab, Isrel. Jakarta : PT. Pustaka Mandiri

Undang-Undang Republik Indonesia Nomor 14 Tahun 2005, 2006, Jakarta : Departemen Pendidikan Nasional

Wijaya Kusumah, 2007, Media Pembelajaran. http://wijayalabs.blogspot.com/2007 12 01 a rchive.html

Yudhi Munadi, 2008, Media Pembelajaran Sebuah Pendekatan Baru, Jakarta : Gaung Persada Press.

Yudhy Wicaksono, Aplikasi Excel dalam Menganalisis Data, Jakarta : Elex Media Komputindo 